BULLETIN OF ENVIRONMENTAL SCIENCE \&
Website: http://journal.hibiscuspublisher.com/index.php/BESSM/index
PUBLISHER

\title{
Isolation of A Molybdenum-reducing Bacillus sp. strain Zeid 15 and Modeling of its Growth on Amides
}

\author{
Abu Zeid, I.M. ${ }^{1}$, Rahman, M.F.A. ${ }^{2}$ and M.Y. Shukor ${ }^{2 *}$ \\ ${ }^{1}$ Department of Biological Sciences, Faculty of Sciences, King Abdulaziz University, \\ P.O. Box 139109, Jeddah 21323, Saudi Arabia \\ ${ }^{2}$ Department of Biochemistry, Faculty of Biotechnology and Biomolecular Sciences, \\ Universiti Putra Malaysia, UPM 43400 Serdang, Selangor, Malaysia. \\ *Corresponding author: \\ Mohd Yunus Shukor, \\ Department of Biochemistry, \\ Faculty of Biotechnology and Biomolecular Sciences, \\ Universiti Putra Malaysia, \\ UPM 43400 Serdang, \\ Selangor, \\ Malaysia. \\ Email: mohdyunus@upm.edu.my/yunus.upm@gmail.com
}

\section{HISTORY \\ Received: $3^{\text {rd }}$ Aug 2021 \\ Received in revised form: $11^{\text {th }}$ Oct 202 Accepted: $28^{\text {th }}$ Nov 2021}

\section{KEYWORDS}

Molybdenum

Molybdenum blue

Bioremediation

Molybdenum reduction

Bacillus sp.

\begin{abstract}
More and more people are looking at bioremediation as a cheaper option to physhiochemical techniques for cleaning up pollution from farming, mines, and other chemical industries. Toxic effects of molybdenum on spermatogenesis harm not only humans but also livestock and aquatic life. As a result, efforts are being made to remove it from the ecosystem. A microorganism that can convert soluble molybdenum into colloidal molybdenum blue has been discovered. Phosphate concentrations were optimum between 2.5 and 5 , molybdate concentrations between 15 and 20, pH between 6, and temperature between 25 and 34 degrees Celsius for the bacteria to thrive. Absorption spectrum of Mo-blue shows a peak at $865 \mathrm{~nm}$ and a shoulder at $700 \mathrm{~nm}$, which indicates that it is in fact reduced phosphomolybdate. Copper, mercury, silver, copper, and chromium are all hazardous heavy metals that hinder the synthesis of Mo-blue. Bacillus sp. strain Zeid 15 is the most likely candidate for the bacterium's identity. As part of our screening, we look for the bacterium's capacity to employ different nitriles and amides as potential electron donors for molybdenum reduction or as substrates for growth. A microplate format was used for the screening. The bacterium was able to use the amides acrylamide and propionamide as sources of electron donor for reduction. Mo-blue production was best supported by acrylamide between 750 and $1250 \mathrm{mg} / \mathrm{L}$, and propionamide between 750 and $1000 \mathrm{mg} / \mathrm{L}$. In addition, these amides including acetamide could support the growth of the bacterium. The modified Gompertz model was utilized to model the growth of this bacterium on amides. The model's growth parameters obtained were lag periods of $1.372,1.562$ and $1.639 \mathrm{~d}$ and maximum specific growth rates of $1.38,0.95$ and $0.734 \mathrm{~d}^{-1}$, for acrylamide, acetamide and propionamide, respectively. The capacity of this bacterium to decontaminate simultaneously amides and molybdenum is a novel characteristic that will be very beneficial in bioremediation.
\end{abstract}

\section{INTRODUCTION}

Heavy metal and organic pollution poisoning of soil and waterways is a severe issue that affects the whole world. Bioremediation has been used extensively to clean up polluted places. Low-concentration contaminants cannot be removed using chemical or physical methods. However, bioremediation is a viable approach [1]. Manufacturing and mining operations are the primary causes of molybdenum pollution in the environment. About $60 \%$ of the world's molybdenum production is used in the steel industry, which is often the source of pollution caused by molybdenum manufacturing processes. Several places associated with the steel industry in Japan, the Black Sea, China, and Austria have been polluted by emissions and aqueous effluents from such enterprises. Molybdenum pollution from an incandescent lightbulb manufacture line in China is one of the greatest reported industry-related contaminations, with values of $252 \mathrm{mg} / \mathrm{kg}$ in soils and $0.5 \mathrm{ppm}$ in groundwater [2]. Mining produces more serious incidents of pollution than industrial activity. Due to seepage from mine tailing's storage depots, the Red River in New Mexico has been contaminated by molybdenum. As a consequence, a neighbouring river habitat has been devastated [3]. Mine tailings waste deposited near the Nver River in western Liaoning, China, has generated a similar scenario in which 
molybdenum contamination of the river with levels considerably beyond the norms has been caused by molybdenum mining operations in the region [4]. Mine tailings waste from the Alaverdi copper molybdenum mine in Armenia is also responsible for the pollution of almost 300 square kilometres of land [5]. In southern Colorado, molybdenum mining activities are responsible for an even higher molybdenum pollution levels where molybdenum concentrations ranging from 900 to 2,000 $\mathrm{mg} / \mathrm{L}$ have contaminated soils and water bodies in the region [6].

The tailings dam from the Miduk copper mine complex in Iran, seeped through the soils and into the groundwater contaminating surrounding agricultural area with copper and molybdenum above the regulatory limits [7]. In Malaysia, seepage and ruptures of pipe carrying molybdenum and copper mine waste cause contamination of agricultural areas including vast areas of paddy fields. The mine is in Ranau, Sabah [8]. In Indonesia, in Batu Hijau, Sumbawa, mining exercise to extract metals from the copper-gold-molybdenum porphyry deposit has progressively contaminate the nearby shoreline zones. The mine deposited over several million tonnes of excess tailings into the nearby sea every year ultimately causing water pollution and decreased fish populations as monitored between the years 2006 and $2010[9,10]$.

Molybdenum can be removed from solution by means of chemical, physical, and biological strategies. Of these methods, biological elimination by means of bacterial reduction is attaining additional consideration as a result of economic aspects. Bacterial reduction of molybdate to the insoluble molybdenum disulphide by sulphate reducing bacteria [11], and to the colloidal molybdenum blue [12] are two such candidates for molybdenum bioremediation. Of the two, the latter is preferred as the bacterial conversion of molybdenum to Mo-blue can be carried out under facultative anaerobic conditions instead of a complete anaerobic conditions in the former [13]. In addition, molybdenum disulphide formation is associated with toxic hydrogen sulphide gas production [11]. Mo-blue-producing bacterial candidates suitable for bioremediation have been reported. These include the bacterium Acinetobacter calcoaceticus [14], E. coli K12 [15], and bacteria from the genera of Klebsiella [16-18], Pseudomonas [14,19], Enterobacter [13,20], Bacillus [21,22], and Serratia [23-26].

Earlier studies on molybdenum toxicity found that ruminants like cattle and sheep are extremely susceptible to low molybdenum concentrations. Copper, sulphur, and molybdenum interactions occurred in the rumen of ruminants. Under anaerobic conditions, reactions between molybdenum and sulphur are accelerated by sulphate-reducing bacteria, resulting in thiomolybdates, which are easily taken into the circulation. Copper is chelated by thiomolybdates, particularly tetrathiomolybdate, lowering its bioavailability in coppercontaining proteins and enzymes [27].

Another significant harmful effect of molybdenum is it suppresses spermatogenesis. Drosophila fed with molybdenum adversely afflicted spermatogenesis. Molybdenum is discovered to impact the early stages of spermatogenesis [28]. The genotoxic effect of molybdenum on spermatogenesis is a result of defect in steroidogenesis and free radical formations [29]. Histopathological and histomorphometric studies of the testes of the mature male Wistar rats subjected to ammonium molybdate reveal irregularities with a decrease in the weight of the testes seen [30]. Analysis of metal content in the muscle of the fish Pangasianodon hypophthalmus in the Mekong Delta indicated the presence of high concentrations of heavy metals including molybdenum. This instigated research on the effect of metal ions, which includes molybdenum on spermatogenesis utilizing the testicular organ culture of the Japanese eel. The results revealed that molybdenum synergistically interact with other metal ions at concentrations of between 0.1 to $10 \mathrm{mg} / \mathrm{L}$ to inhibit spermatogenesis [31].

Acrylamide (Fig. 1) is a toxic xenobiotic. It is the building block for the polymer, polyacrylamide. This polymer has many uses such as stabilising tunnels and dams, as sewage-flocculating agents, and as industrial adhesives [32]. It has been reported in Sweden that acrylamide poisoning caused by environmental contamination has caused the death of cows and fish [33], among other animals. Polyacrylamide is used as a dispersion agent in the composition of the herbicide glyphosate [34], and it is possible that this is a significant source of acrylamide pollution in soils and run-off. At levels as high as $1 \mathrm{~g} / \mathrm{L}$, the acrylonitrile and the acrylamide factories have been recognised as major acrylamide pollution sources. [35] in the aforementioned industries.<smiles>C=CC(N)=O</smiles>

(a)<smiles>CC(N)=O</smiles>

Fig. 1. The structure of acrylamide (a) and acetamide (b).

Heavy metals, amides, and other toxins abound in polluted environments. The capacity to employ amides as an electron donor for reduction or growth was tested in this context using an agricultural soil molybdenum-reducing bacterium. We discovered that the bacterium could use the amides as electron donor and also for growth. Another amide: was not able to act as electron donor but can be used as a carbon source for growth. The screening and characterization of molybdenum reduction was carried out in a microplate or microtiter plate.

\section{MATERIALS AND METHODS}

\section{Isolation, maintenance and partial identification of Mo- reducing bacterium}

An agricultural land in the city of Juba, South Sudan, Africa was chosen as the site of soil sampling carried out in 2012. Soil sample was scooped $5 \mathrm{~cm}$ from the topsoil and transfer into a sterile polypropylene container. Potential candidates of molybdenum-reducing bacteria were isolated using a minimal salts media (MSM). The media had the phosphate and molybdate concentrations set at 5 and $10 \mathrm{mM}$, respectively. This is low phosphate molybdate media or LPM. As the LPM media causes bacterial clumping, a high phosphate molybdate (HPM) media for growth of resting cells was opted with the composition of the medium was the same to the LPM media, but with the critical difference where the phosphate concentration was increased to $100 \mathrm{mM}$ to avoid Mo-blue production.

A soil suspension was made by combining one gram of soil in $10 \mathrm{ml}$ of tap water and was completely blended. A $0.1 \mathrm{~mL}$ of the soil suspension was then spread onto a petri dish containing a solid media (w/v) adjusted to $\mathrm{pH} 6.5$ as follows: Agar (1.5\%), $\mathrm{NaCl}(0.5 \%)$, yeast extract $(0.5 \%)$, agar $(1.5 \%),\left(\mathrm{NH}_{4}\right)_{2} \cdot \mathrm{SO}_{4}$ $(0.3 \%), \mathrm{MgSO}_{4} \cdot 7 \mathrm{H}_{2} \mathrm{O}(0.05 \%)$, glucose $(1 \%), \mathrm{Na}_{2} \mathrm{MoO}_{4} \cdot 2 \mathrm{H}_{2} \mathrm{O}$ $(0.242 \%$ or $10 \mathrm{mM})$, and $\mathrm{Na}_{2} \mathrm{HPO}_{4}(0.071 \%$ or $5 \mathrm{mM})$ [18]. At room temperature incubation for $48 \mathrm{~h}$ resulted in the formation of a number of white blue colonies on the plate. In order to cleanse the bacteria, the ten isolates were moved onto another 
LPM agar plate on a regular basis. A $100 \mathrm{~mL}$ liquid (LPM) culture was used to produce Mo-blue in order to select the best isolate from the batch of isolates. Depending on phenotypical and biochemical procedures described in Bergey's Manual of Determinative Bacteriology, the identification of the Moreducing bacteria was accomplished [36]. The results were computed into the online bacterial identification system or ABIS [37].

\section{Absorption spectra for Mo-blue produced}

LPM was used as the baseline correction for scanning the molybdenum blue absorption spectrum between 400 and $900 \mathrm{~nm}$ using a UV-visible range spectrophotometer (Shimadzu 1201) and the molybdenum blue absorption spectrum.

\section{Preparation of bacterial resting cells for Mo-blue production characterization}

The same as previously, a microtiter format was used to describe molybdenum reduction in order to determine the concentrations of phosphate and molybdate, as well as the impacts of temperature, $\mathrm{pH}$, carbon sources and heavy metals. The experiments were performed at room temperature [38]. To summarise, bacterial cells were cultured aerobically on an orbital shaker $(120 \mathrm{rpm})$ in a series of $250 \mathrm{~mL}$ shake flasks with a total capacity of $1 \mathrm{~L}$. The shaking mechanism was an orbital shaker. The medium utilised was High Phosphate Media (HPM), with the primary difference between it and Low Phosphate Media (LPM) being the phosphate concentration, which was set at $100 \mathrm{mM}$. Bacterial cells were first centrifuged at $10,000 \mathrm{~g}$ for $10 \mathrm{~min}$ at 4 degrees Celsius. To eliminate any leftover germs, the formed bacterial pellets were rinsed twice with deionized water. Following that, the pellet was resuspended in $20 \mathrm{~mL}$ of LPM without the addition of glucose.

Adjustments to the LPM medium were found to be necessary to accommodate the various characterization approaches outlined before. Using sterile procedures, $180 \mathrm{~mL}$ of media was pipetted into the flat-bottom microplate wells. Sterile glucose $(20 \mathrm{~mL})$ was added to the final concentration to obtain a final concentration of 1.0 percent $(\mathrm{w} / \mathrm{v})$. The maximum volume was 200 microlitres. A two-day period of incubation at room temperature was followed by the sealing of the microplates. The amount of Mo-blue produced was measured using a BioRad Microtiter Plate reader at $750 \mathrm{~nm}$ (Model No. 680, Richmond, CA). For the purpose of quantifying Mo-blue generation [38], an extinction coefficient of $11.69 \mathrm{mM} \cdot{ }^{-1} \cdot \mathrm{cm}^{-1}$. was measured at 750 $\mathrm{nm}$. Heavy metals were supplied from standard solutions for Atomic Absorption Spectrometry (AAS) analysis (Merck KGaA, Darmstadt, Germany).

\section{Test of amides and nitriles as sources of electron donor or growth}

At $1,000 \mathrm{mg} / \mathrm{L}$, several amides and nitriles were evaluated. Simply said, 200 mcirolitres of medium was combined with 50 microlitres of resting cell suspension in microplate wells and grown at room temperature for $96 \mathrm{~h}$. The synthesis of Mo-blue was monitored using a microplate reader to determine the absorbance at $750 \mathrm{~nm}$. If the bacteria is unable to use the amides and nitriles as electron donors for Mo-blue synthesis (molybdenum reduction), the amides and nitriles were evaluated for their capacity to maintain growth in their absence. [39].

The ingredients of the growth media (LPM) at $\mathrm{pH} 7.0$, were as follows: $\mathrm{NaNO}_{3}(0.2 \%), \mathrm{NaCl}(0.5 \%), \mathrm{MgSO}_{4} \cdot 7 \mathrm{H}_{2} \mathrm{O}(0.05 \%)$, $\left(\mathrm{NH}_{4}\right)_{2} \cdot \mathrm{SO}_{4}(0.3 \%)$, yeast extract $(0.01 \%)$ and $\mathrm{Na}_{2} \mathrm{HPO}_{4}(0.705 \%$ or $50 \mathrm{mM})$.
Bacterial growth at room temperature was monitored at $600 \mathrm{~nm}$ after $96 \mathrm{~h}$ of static incubation.

\section{HPLC analysis of acrylamide degradation}

HPLC analysis (Agilent, 1100 series) was utilised to confirm the degradation of acrylamide, which results in the creation of acrylic acid. The standard was acrylic acid of analytical grade obtained from Sigma (St. Louis, Missouri, United States of America). The reverse phase column (Supelco Discovery ${ }^{\circledR}$ HS C18) measures $4.6 \times 150 \mathrm{~mm}$ and has a particle size of $5 \mathrm{~mm}$ (Sigma-Aldrich Co., USA). To eliminate bacterial contamination of the system, a suitable sample of the bacterial culture was centrifuged at 10,000 $\mathrm{g}$ for $10 \mathrm{~min}$. A $20 \mathrm{~mL}$ sample was introduced into the system using a 0.45 -micron polytetrafluoroethylene (PTFE) filter from an appropriate aliquot. The flow rate was $0.5 \mathrm{~mL}$ per minute, using ultrapure water as the mobile phase. The detection wavelength in this experiment was $196 \mathrm{~nm}$, with a reference wavelength of $360 \mathrm{~nm}$ [40].

\section{RESULTS AND DISCUSSIONS}

Molybdenum or molybdate (sodium salt) reduction to Mo-blue is first mentioned in E. coli nearly over a century ago in 1896 [12]. This was followed by Serratia sp. [41]. However, Campbell et al. initiated the first detailed study of the phenomenon in mutant cells in 1985 in E. coli K12 [15]. Ghani et al. reported the phenomenon again in 1993 in the bacterium Enterobacter cloacae strain 48 but was unaware of any previous heterorophic molybdate reduction to Mo-blue mentioned previously [13] Ghani et al. was the first to suggest the utility of this bacterium for bioremediation [13]. Since then, numeorus Mo-reducing bacteria have been isolated (Table 1).

\section{Identification of Mo-reducing bacterium}

Ten microbial isolates with the ability to reduce molybdenum to Mo-blue were the grown in liquid LPM media. The best isolate with the highest Mo-blue production was isolate ix (Table 2). This isolate was then further identified, and its Mo-blue production characterized. The bacterium was an aerobic Grampositive bacterium. Partial identification was carried out based on (Table 3) the Bergey's Manual of Determinative Bacteriology [43] and plugging the results into the ABIS online software [37]. The software gave two suggestions for the bacterial identity as Bacillus subtilis or Bacillus atrophaeus with the same $91 \%$ homology and 94\% accuracy, indicating assignment to the species level cannot be done. Despite this, we are carrying out further molecular identification technique by analyzing the 16srRNA gene of this bacterium. At this moment the bacterium is identified as Bacillus sp. strain Zeid 15.

Previously, two Mo-reducing bacteria from this genus; Bacillus pumilus strain lbna [21] and Bacillus sp. strain A.rzi [22] have been isolated and characterized. The effect of heavy metals to Molybdenum reduction showed that mercury, silver, copper and chromium at $2 \mathrm{ppm}$ inhibited Mo-bleu synthesis by 83.0, $70.3,61.1$ and $40.1 \%$, respectively, (data not shown) suggesting that mercury was the strongest inhibitor. The sulfhydryl group is a probable target for inhibition similar to works in bacterial chromate reduction where the heavy metals mercury and copper were found to bind to the sulfhydryl group of chromate reductase, inhibiting the reduction $[44,45]$. 
Table 1. Characterization of Mo-reducing bacteria isolated to date.

\begin{tabular}{|c|c|c|c|c|c|}
\hline $\begin{array}{l}\text { Optimal } \\
\text { C source }\end{array}$ & $\begin{array}{l}\text { Optimal } \\
\text { Phosphate } \\
(\mathrm{mM})\end{array}$ & $\begin{array}{l}\text { Optimal } \\
\text { Molybdate } \\
(\mathrm{mM})\end{array}$ & Bacteria & Heavy metals inhibition & Ref \\
\hline glucose & $5-7.5$ & $5-20$ & $\begin{array}{l}\text { Klebsiella } \\
\text { oxytoca strain } \\
\text { Aft-7 }\end{array}$ & $\mathrm{Cu}^{2+}, \mathrm{Ag}^{+}, \mathrm{Hg}^{2+}$ & [18] \\
\hline glucose & 4 & 50 & $\begin{array}{l}\text { Bacillus sp. } \\
\text { strain A.rzi }\end{array}$ & $\begin{array}{l}\mathrm{Cd}^{2+}, \mathrm{Cr}^{6+}, \mathrm{Cu}^{2+}, \mathrm{Ag}^{+} \\
\mathrm{Pb}^{2+}, \mathrm{Hg}^{2+}, \mathrm{Co}^{2+}, \mathrm{Zn}^{2+}\end{array}$ & {$[22]$} \\
\hline glucose & $2.5-5$ & 40 & $\begin{array}{l}\text { Bacillus } \\
\text { pumilus strain } \\
\text { lbna }\end{array}$ & $\begin{array}{c}\mathrm{As}^{3+}, \mathrm{Pb}^{2+}, \mathrm{Zn}^{2+}, \mathrm{Cd}^{2+} \\
\mathrm{Cr}^{6+}, \mathrm{Hg}^{2+}, \mathrm{Cu}^{2+}\end{array}$ & [21] \\
\hline glucose & 5 & $30-50$ & \begin{tabular}{ll}
\multicolumn{2}{l}{ Pseudomonas } \\
sp. & strain \\
DRY1 &
\end{tabular} & $\begin{array}{c}\mathrm{Cd}^{2+}, \mathrm{Cr}^{6+}, \mathrm{Cu}^{2+}, \mathrm{Ag}^{+} \\
\mathrm{Pb}^{2+}, \mathrm{Hg}^{2+}\end{array}$ & [19] \\
\hline fructose & 4.5 & 80 & $\begin{array}{l}\text { Klebsiella } \\
\text { oxytoca strain } \\
\text { hkeem }\end{array}$ & $\mathrm{Cu}^{2+}, \mathrm{Ag}^{+}, \mathrm{Hg}^{2+}$ & [16] \\
\hline glucose & 5 & 20 & $\begin{array}{l}\text { Acinetobacter } \\
\text { calcoaceticus } \\
\text { strain Dr.Y12 }\end{array}$ & $\begin{array}{c}\mathrm{Cd}^{2+}, \mathrm{Cr}^{6+}, \mathrm{Cu}^{2+}, \mathrm{Pb}^{2+}, \\
\mathrm{Hg}^{2+}\end{array}$ & [42] \\
\hline sucrose & 5 & 20 & $\begin{array}{l}\text { S. marcescens } \\
\text { strain Dr.Y9 }\end{array}$ & $\mathrm{Cr}^{6+}, \mathrm{Cu}^{2+}, \mathrm{Ag}^{+}, \mathrm{Hg}^{2+}$ & [26] \\
\hline sucrose & 5 & 50 & $\begin{array}{l}\text { Serratia sp. } \\
\text { strain Dr.Y8 }\end{array}$ & $\mathrm{Cr}, \mathrm{Cu}, \mathrm{Ag}, \mathrm{Hg}$ & [25] \\
\hline glucose & 5 & $15-20$ & 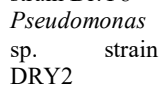 & $\mathrm{Cr}^{6+}, \mathrm{Cu}^{2+}, \mathrm{Pb}^{2+}, \mathrm{Hg}^{2+}$ & [14] \\
\hline glucose & 5 & 30 & $\begin{array}{l}\text { Serratia sp. } \\
\text { strain Dr.Y5 }\end{array}$ & n.a. & [24] \\
\hline glucose & 5 & $25-50$ & \begin{tabular}{lr}
\multicolumn{2}{l}{ Enterobacter } \\
sp. & strain \\
Dr.Y13 &
\end{tabular} & $\begin{array}{c}\mathrm{Cr}^{6+}, \mathrm{Cd}^{2+}, \mathrm{Cu}^{2+}, \mathrm{Ag}^{+} \\
\mathrm{Hg}^{2+}\end{array}$ & [20] \\
\hline sucrose & 5 & $15-25$ & $\begin{array}{l}\text { Serratia } \\
\text { marcescens } \\
\text { strain DRY6 }\end{array}$ & $\mathrm{Cr}^{6+}, \mathrm{Cu}^{2+}, \mathrm{Hg}^{2+}$ & [23] \\
\hline sucrose & 2.9 & 20 & $\begin{array}{l}\text { Enterobacter } \\
\text { cloacae strain } \\
48\end{array}$ & $\mathrm{Cr}^{6+}, \mathrm{Cu}^{2+}$ & [13] \\
\hline glucose & 5 & 80 & $\begin{array}{l}\text { Escherichia } \\
\text { coli } \mathrm{K} 12\end{array}$ & $\mathrm{Cr}^{6+}$ & [15] \\
\hline
\end{tabular}

Table 2. Mo-blue production screening by soil bacterial isolates.

\begin{tabular}{llrl}
\hline Isolate & \multicolumn{3}{l}{$\begin{array}{l}\text { A 750 } \\
\mathrm{n}=3) .\end{array}$} \\
& 0.42 & \pm & ( \\
& standard deviation, \\
i & 0.41 & \pm & 0.04 \\
ii & 0.79 & \pm & 0.03 \\
iii & 1.07 & \pm & 0.12 \\
iv & 0.75 & \pm & 0.04 \\
v & 0.79 & \pm & 0.02 \\
vi & 1.11 & \pm & 0.07 \\
vii & 1.12 & \pm & 0.06 \\
viii & 1.75 & \pm & 0.05 \\
ix & 0.39 & \pm & 0.05 \\
x & & &
\end{tabular}

\section{Molybdenum absorbance spectrum}

As part of the molybdate reduction process, aliquots of the culture medium supernatant were scanned from 400 to $1000 \mathrm{~nm}$ at different times over a period of several days. Spectroscopic analysis revealed a major peak at $865 \mathrm{~nm}$ and a shoulder at 700 $\mathrm{nm}$ in the acquired spectrum. Through the duration of the incubation period, this distinct profile remained intact (Fig. 2). One proposed process for molybdenum reduction in bacteria is speculated to begin with an enzymatic reduction of Mo6+ to the oxidation state of Mo5+. This is in accordance with prior recommendations. This is followed by the entrance of phosphate ions, which results in the formation of Mo-blue [13]. The synthesis of phosphomolybdate from molybdate is a difficult chemical reaction to understand. When molybdate concentrations were more than $1 \mathrm{mM}$ and acidic $\mathrm{pH}$ conditions were present, molybdate ions produced polyions, including $\mathrm{H}_{2} \mathrm{Mo}_{7} \mathrm{O}_{24} 4^{4-}$, $\mathrm{HMo}_{7} \mathrm{O}_{24}{ }^{5-}, \mathrm{Mo}_{7} \mathrm{O}_{24}{ }^{6-}$, and $\mathrm{Mo}_{12} \mathrm{O}_{37^{2-}}$, among others.

$\begin{array}{lcl}\text { Gram positive staining } & + & \text { Acid production from: } \\ \text { Motility } & + & \text { N-Acetyl-D- } \\ & & \text { Glucosamine } \\ \text { Growth on usual media * } & + & \text { Cellobiose } \\ \text { Growth at } 45^{\circ} \mathrm{C} & + & \text { Fructose } \\ \text { Growth at } 65^{\circ} \mathrm{C} & - & \text { L-Arabinose } \\ \text { Hemolysis } & + & \text { D-Glucose } \\ \text { Growth at pH } 5.7 & + & \text { Glycogen } \\ \text { Anaerobic growth } & - & \text { Glycerol } \\ \text { Growth on } 7 \% \text { NaCl media } & + & \text { Lactose } \\ \text { Casein hydrolysis } & + & \text { meso-Inositol } \\ \text { Growth in Lysozyme (0.001\%) } & - & \text { D-Mannose } \\ \text { Gelatin hydrolysis } & + & \text { Mannitol } \\ \text { Esculin hydrolysis } & + & \text { Melezitose } \\ \text { Tyrosine degradation } & - & \text { Maltose } \\ \text { Starch hydrolysis } & + & \text { Raffinose } \\ \text { Catalase } & + & \text { Melibiose } \\ \text { Beta-galactosidase (ONPG) } & + & \text { Ribose } \\ \text { Urease } & - & \text { Rhamnose } \\ \text { Oxidase } & \text { d } & \text { Sorbitol } \\ \text { Lysine decarboxylase (LDC) } & - & \text { Salicin } \\ \text { Arginine dehydrolase (ADH) } & - & \text { Starch } \\ \text { Citrate utilization } & + & \text { Sucrose } \\ \text { Ornithine decarboxylase (ODC) } & - & \text { D-Xylose } \\ \text { Nitrates reduction } & + & \text { Trehalose } \\ \text { Egg-yolk reaction } & - & \\ \text { Voges-Proskauer test (VP) } & + & \\ \text { Note: + positive result, }- \text { negative result, d indeterminate result }\end{array}$

As the $\mathrm{pH}$ of the solution is reduced to less than 2.0, the formation of species such as $\mathrm{Mo}_{8} \mathrm{O}_{26}{ }^{4-}$ and $\mathrm{Mo}_{36} \mathrm{O}_{112}\left(\mathrm{H}_{2} \mathrm{O}\right)_{16}{ }^{8-}$ began, with more complicated species developing as the $\mathrm{pH}$ of the solution was reduced even further. Polyoxomolybdates are the chemical name for this kind of molybdenum. The structure may include heteroatoms such as silicate or phosphate, with the latter producing the heteropolyoxomolybdate phosphomolybdate structure in its final state of formation [46]. $\mathrm{PMo}_{12} \mathrm{O}_{40} 0^{-3}$ has been proved to be the phosphomolybdate synthesised using the phosphate determination technique, with a-Keggin structure, and this has been confirmed experimentally.

As the molecule undergoes further reduction by ascorbic acid, it is transformed to the keggin ion, $\mathrm{PMo}_{12} \mathrm{O}_{40}{ }^{-7}$, which is molybdenum blue in appearance [47]. The heteropolymolybdates phosphomolybdate and silicomolybdate are electron acceptor substrates in enzymes such as xanthine- and aldehyde oxidase where these enzyme convert these heteropolymolydate into Moblue [48-50]. The resulting molybdenum blue spectra from this and numerous other Mo-reducing bacteria are almost identical to the phosphate determination method (PDM), where the Mo-bleu produced in this method is reduced phosphomolybdate [18,51]. The Mo-blue from the PDM has a shoulder between 700 and 720 $\mathrm{nm}$ and a peak maximum between $870 \mathrm{~nm}$ and $890 \mathrm{~nm}[49,52]$.

Using fingerprint spectra to demonstrate the existence of the phosphomolybdate intermediate, we propose a novel hypothesis that the intermediate created during molybdate reduction in bacteria is phosphomolybdate, rather than molybdate, as previously thought [13], which is reduced to Mo-blue [51]. In bacterial chromate reduction from $\mathrm{Cr}^{6+}$ to $\mathrm{Cr}^{3+}$, an intermediate species of $\mathrm{Cr}^{5+}$ is observed, and confirmed via spectroscopic and paramagnetic resonance analyses [53]. The spectroscopic approach as utilized in this work is considered well suited for differentiating between the heteropolymolybdates for instance phosphomolybdate, silicomolybdate, and sulfomolybdate. Additional examination, including the use of electron spin resonance and nuclear magnetic resonance and will be necessary in order to determine the identification of the specific lacunary species of phosphomolybdate discovered in this research $[49,54]$.

Table 3. Biochemical tests for Bacillus sp. strain Zeid 15. 


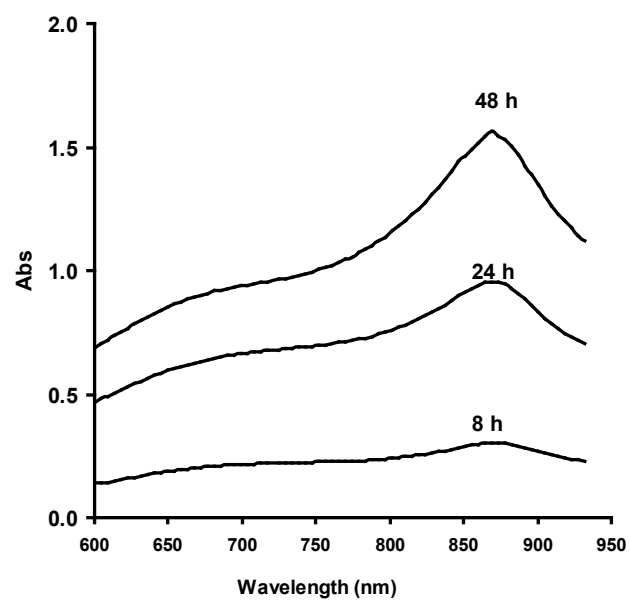

Fig. 2. Mo-blue scanning absorption spectra from from Bacillus sp. strain Zeid 15 at different time intervals.

\section{Mo-blue production at various temperatures and $\mathrm{pHs}$}

The effect of $\mathrm{pH}$ to Mo-blue production by Bacillus sp. strain Zeid 15 was studied at different initial $\mathrm{pHs}$ ranging from 5.5 to 8.0. The optimum $\mathrm{pH}$ as analyzed by ANOVA indicated that reduction was optimum between the pHs 6.0 and 6.5 (Fig. 3). The range of temperature utilized for optimization studies ranged from 20 to $60{ }^{\circ} \mathrm{C}$. The optimum temperature was found to be between 25 and $30^{\circ} \mathrm{C}$ as analyzed using ANOVA. A dramatic decline in Mo-blue production occurred at temperatures higher than $30{ }^{\circ} \mathrm{C}$, with no Mo-blue produced at $40{ }^{\circ} \mathrm{C}$ (Fig. 4).

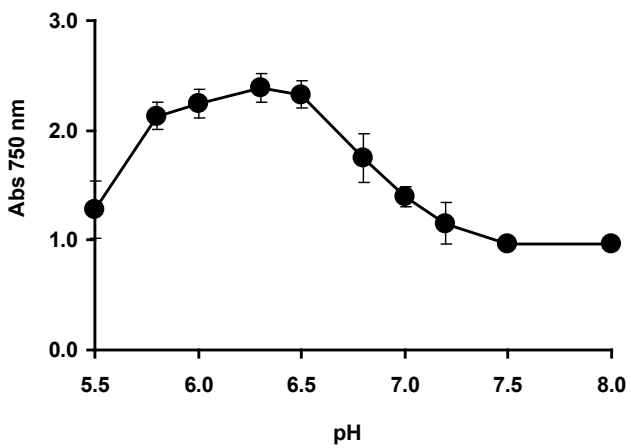

Fig. 3. Molybdate reduction to Mo-blue at various pHs. The error bars are averaged or mean \pm standard deviation $(\mathrm{n}=3)$.

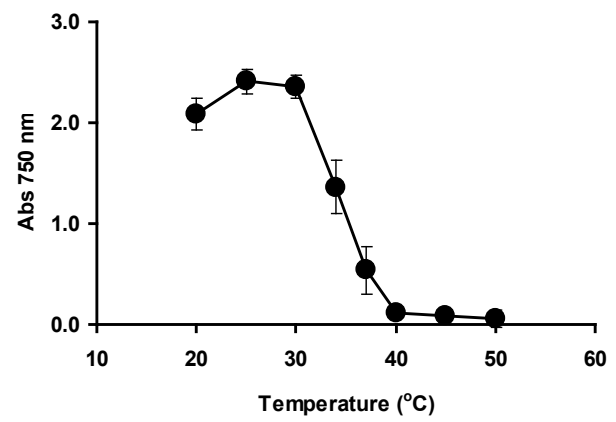

Fig. 4. Molybdate reduction to Mo-blue at various temperatures. The error bars are averaged or mean \pm standard deviation $(\mathrm{n}=3)$.

The optimum temperature range exhibited by this bacterium is an advantage for future bioremediation works in Sudan where the yearly temperature average ranged from 17 to $42^{\circ}$. Recently isolated Mo-reducing bacteria exhibited optimum temperature range from 25 to $37^{\circ} \mathrm{C}$ as all of them are isolated from tropical environment with the exception of one bacterium isolated from Antarctica (Table 1). The optimal $\mathrm{pH}$ range exhibited by this bacterium reflects the characteristics of a neutrophile, the latter exhibited optimal growth at $\mathrm{pH}$ ranging from $\mathrm{pH} 5.5$ to 8.0 [55]. Most of the Mo-reducing bacteria show reduction within this range (Table 1).

Mo-blue production using various potential electron donors Glucose was shown to be the most effective electron source for reducing molybdenum. Higher glucose concentrations (data not given) inhibited glucose decrease because of osmotic stress, and the ideal glucose concentration was 1 percent (w/v) [20]. The next best carbon sources were fructose, sucrose, maltose, trehalose, ribose, glycogen, d-mannose, lactose, melibiose, meso-inositol and glycerol in descending order (Fig. 5). Numerous metal bacterial reductions such as arsenate [56], selenate [57], chromate [58] and vanadate [59] utilize either glucose, lactate or formate as optimal electron donors.

Many of the Mo-reducing bacteria isolated require glucose or sucrose for molybdenum reduction (Table 1). Molybdate reduction requires $\mathrm{NADH}$ or $\mathrm{NADPH}$ as direct substrates of electron donors. These carbon sources can produce these substrates through ubiquitous bacterial metabolic pathways $[13,50,60]$, thus explaining the preference observed. However, actual bioremediation works need a cheaper carbon source, and currently molasses fits the requirement as it is plentiful in Sudan as a sugarcane waste products [61].

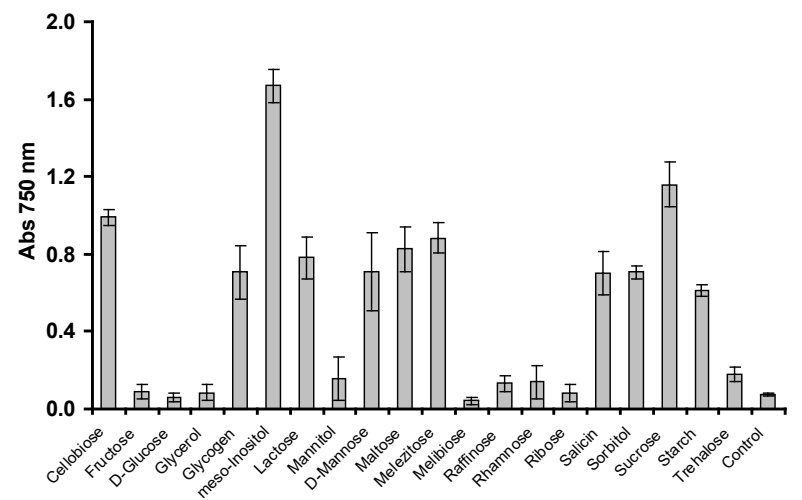

Fig. 5. Molybdate reduction to Mo-blue using various electron donor sources. The error bars are averaged or mean \pm standard deviation $(n=3)$.

\section{Phosphate and molybdate concentrations effects to molybdate reduction}

It was found that the optimal concentration of phosphate was in the range of 2.5 and $5.0 \mathrm{mM}$, with greater amounts being substantially inhibitory to the reduction process (Fig. 6). The best reduction range was found to be between 15 and $20 \mathrm{mM}$. (Fig. 7). Phosphate concentrations over a certain threshold are shown to impede molybdenum reduction to Mo-blue in bacteria in a number of early investigations. The reduction of E. coli K12 is hindered by phosphate concentrations more than $5 \mathrm{mM}$, but in $\mathrm{E}$. coli 48 , values greater than $2.9 \mathrm{mM}$ have been observed to be inhibitory [13].

Generally, in most of the recently isolated Mo-reducing bacteria, phosphate concentrations higher than $5 \mathrm{mM}$ are inhibitory (Table 1). The reason for this requirement lies probably in the chemical basis of phosphomolybdate stability. This compound requires acidic $\mathrm{pH}$ for its stability, and at neutral $\mathrm{pH}$ it is destabilized by rapid oxidation [48]. Because its $\mathrm{pKa}$ is so close to neutral, 
phosphorus is an excellent buffer, particularly at neutrality. $\mathrm{pH}$ of the solution is substantially buffered at neutral $\mathrm{pH}$ when quantities of $20 \mathrm{mM}$ and greater are used to make the solution. In certain cases, the destabilisation of phosphomolybdate might be caused by the action of phosphate itself.

An acidified $100 \mathrm{mM}$ phosphate solution destabilises an ascorbate-reduced phosphomolybdate, often known as Mo-blue, in a short period of time [62]. Table 1 demonstrates that, in general, the ideal sodium molybdate concentrations for Mo-blue synthesis range from 5 to $80 \mathrm{mM}$ in concentration. Antibioticresistant bacteria, in contrast to cationic heavy metals, are capable of tolerating and even reducing high amounts of anionic heavy metals. For example, the most tolerant bacterium is capable of tolerating and reducing chromate at $30 \mathrm{mM}$ concentrations in Pseudomonas putida [63], arsenate at $60 \mathrm{mM}$ in Citrobacter sp. NC-1 [56] selenate at $20 \mathrm{mM}$ in Bacillus sp. [64], and vanadate at $50 \mathrm{mM}$ in Pseudomonas isachenkovii [59].

Thus, the majority of these Mo-reducing bacteria can be utilized to cleanup sites polluted with molybdenum at elevated concentrations. Several sites In South Dakota have been discovered to be polluted with molybdenum as high as 6,500 $\mathrm{mg} / \mathrm{Kg}$ in soils or approximately $68 \mathrm{mM}$ and $900 \mathrm{mg} / \mathrm{L}$ or approximately $9.4 \mathrm{mM}$ in water [65]. For efficient remediation, phosphate concentrations in sites polluted with molybdenum should not exceed $20 \mathrm{mM}$ as this would inhibit molybdenum reduction. It is fortunate that phosphate concentrations in a variety of soils and water bodies rarely exceeded this value [66], allowing molybdenum reduction to take place unhindered.

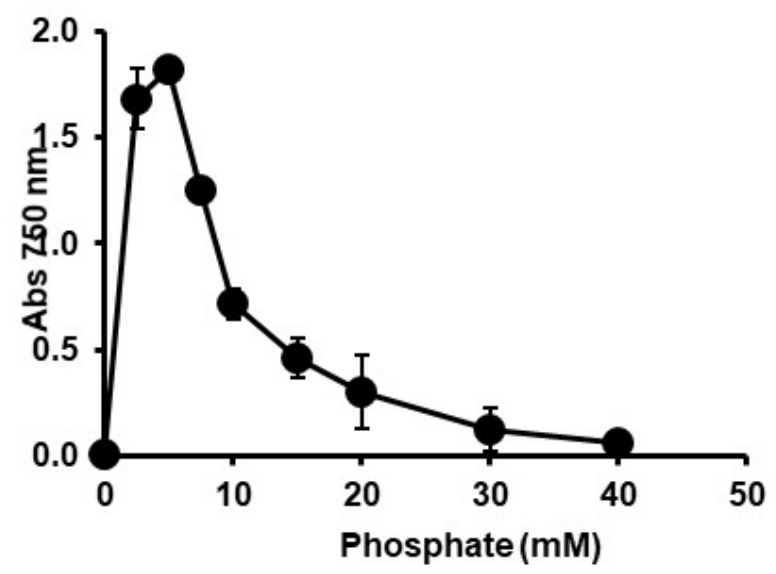

Fig. 6. Molybdenum blue production at varying phosphate levels. The error bars are averaged or mean \pm standard deviation $(n=3)$.

\section{Amides and nitriles as sources of electron donors for Mo-blue production or growth only}

Acrylamide and propionamide were found to promote molybdenum reduction at a lesser efficiency than glucose, whereas the other xenobiotics examined were shown to be incapable of supporting molybdenum reduction at all. Several of the amides listed above, including acetamide, may be able to maintain the development of this bacteria without the need for molybdenum reduction (Fig. 8). Mo-blue production was optimum when acrylamide was between 750 and $1250 \mathrm{mg} / \mathrm{L}$, and propionamide was between 750 and $1000 \mathrm{mg} / \mathrm{L}$. Amides at higher concentrations were inhibitory to Mo-blue production (Fig. 9).

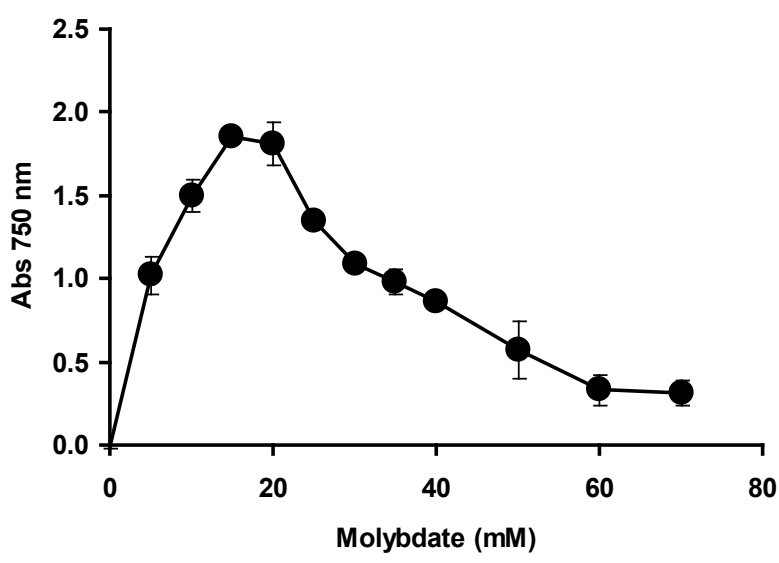

Fig. 7. Molybdenum blue production at varying sodium molybdate levels. The error bars are averaged or mean \pm standard deviation $(n=3)$.

The modified Gompertz model was utilized to model the growth of this bacterium on these amides (Fig. 10). One of the perquisites of this model is the absorbance values need to be converted to natural logarithm. The growth parameters obtained were maximum specific growth rates of $0.95,1.38$, and $0.734 \mathrm{~d}^{-1}$ and lag periods of $1.562,1.372$ and $1.639 \mathrm{~d}$, for acetamide, acrylamide, and propionamide, respectively. The model showed correlation coefficients of $0.99,0.98$ and 0.99 for acrylamide, acetamide and propionamide respectively, indicating a good agreement between observed and predicted values. The highest specific growth rate and the lowest lag period indicate that acrylamide is the most preferred substrate for this bacterium, while conversely, propionamide was the least preferred substrate.

The degradation of acrylamide was confirmed by the presence of acrylic acid based on HPLC analysis (Fig. 11). It remains to be studied why acetamide cannot aid molybdenum reduction even though it is a linear amide similar to acrylamide, acetamide and propionamide. Aromatic amides are difficult to be degraded and hence not benig able to be used by the bacterium either as sources for electron donors or growth. Literature search showed that there is an absence of growth modelling data for bacteria on amides as substrates for growth, and the modeling activity carried out in this work may be the first case of the successful use of the modified Gompertz model.

The ability of the amides to support molybdenum reduction has never been reported and is considered novel. In chromate reduction, carbon source other than simple carbohydrates such as phenol and pyrene have been reported for their capability to support reduction [67]. These amides are being produced over several millions of tonnes annually. Microorganisms that can grow on amides include Pseudomonas azotoformans [68], Variovorax boronicumulans CGMCC 4969 [69], Pseudomonas putida [70], Pseudomonas aeruginosa [71],Stenotrophomonas acidaminiphila MSU1 [72], Pseudomonas sp. [40], Enterobacter aerogenes [73], Thermococcus hydrothermalis [74], Pseudomonas acidovorans [75], Pseudomonas chlororaphis [76], Bacillus cereus [77], Pseudonocardia thermophilia, Burkholderia sp. [78], Rhodococcus sp. [79], Kluyvera georgiana [80] and the yeast Rhodotorula sp. [32] with all of these microorganisms suggested as potential bioremediation agents for amide pollutions. 


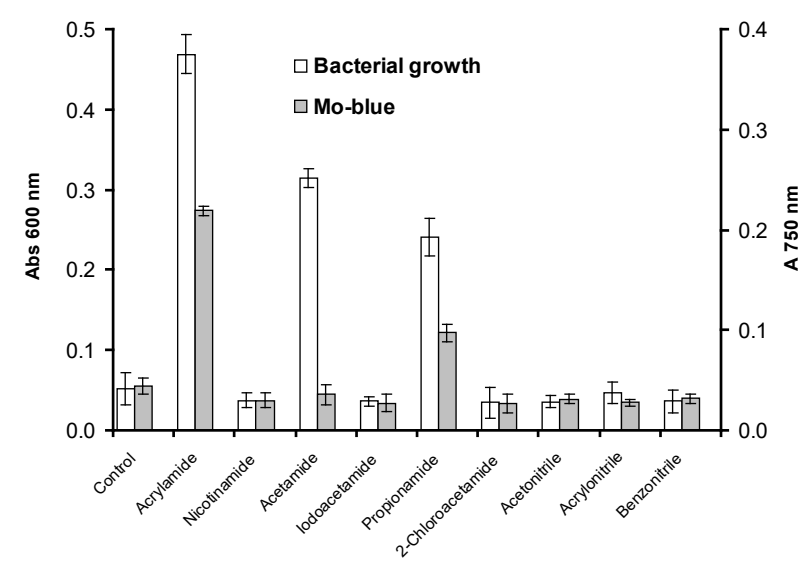

Fig. 8. Xenobiotics as electron donors for Mo-blue production and growth of Bacillus sp. strain Zeid. The error bars are averaged or mean \pm standard deviation $(\mathrm{n}=3)$.

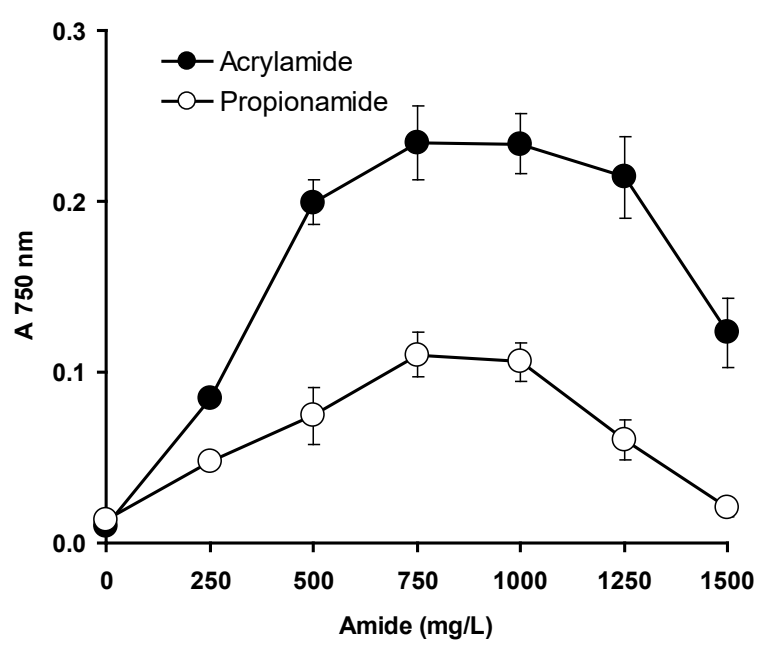

Fig. 9. Bacillus sp. strain Zeid 15 Mo-blue production with acrylamide and propionamide as electron donor sources. The error bars are averaged or mean \pm standard deviation $(n=3)$.

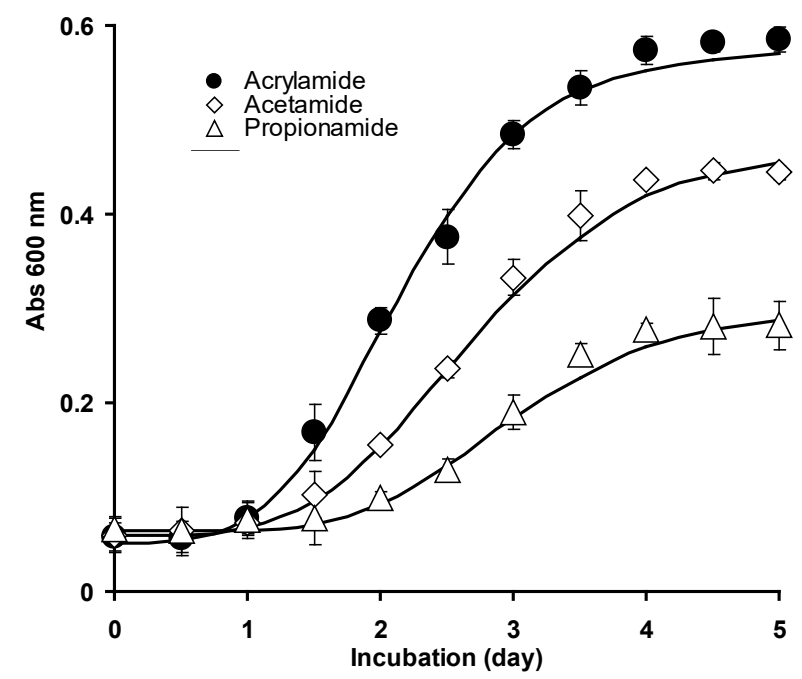

Fig. 10. The use of the modified Gompertz model (solid lines)in modelling the growth of Bacillus sp. strain Zeid 15 on propionamide, acrylamide and acetamide. The error bars are averaged or mean \pm standard deviation $(\mathrm{n}=3)$.
$\mathbf{A}$

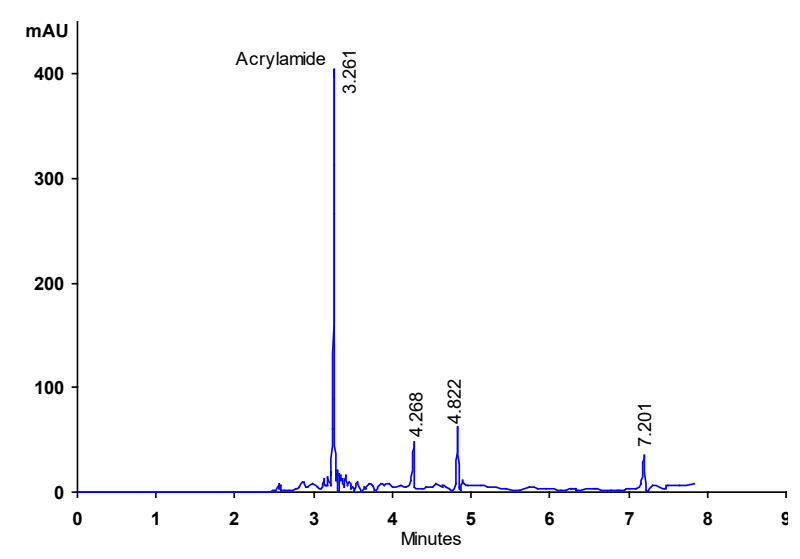

B

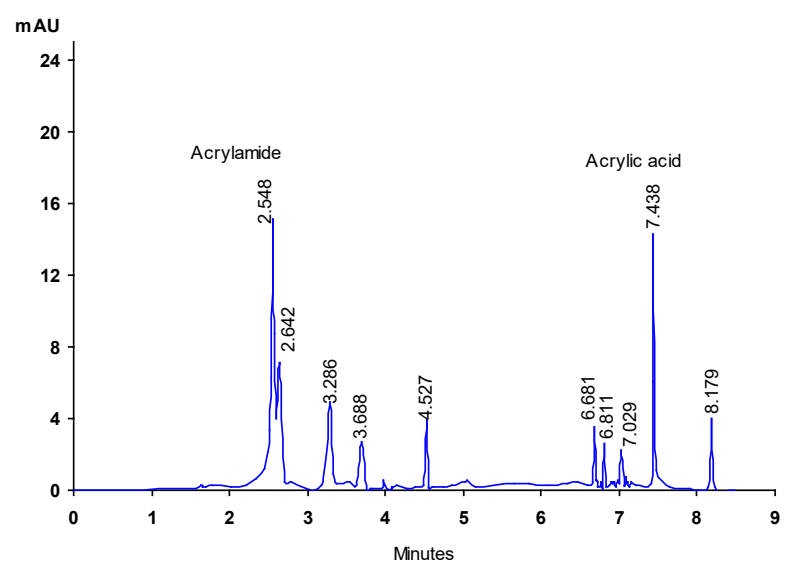

Fig. 11. HPLC chromatogram of acrylamide at the start of incubation (A) and acrylic acid detection during acrylamide degradation (B).

\section{CONCLUSION}

Using a process that reduces molybdenum to colloidal molybdenum blue might be a viable option for molybdenum bioremediation. The need to remove molybdenum from the environment is projected to grow since more recent research indicates that it is hazardous to spermatogenesis at low doses. Using acrylamide and propionamide as electron donors for molybdenum reduction, we isolated a molybdenum-reducing bacteria. Glucose, on the other hand, remains the finest available electron donor. A third amide, called acetamide, may help encourage this bacterium's development but not its decrease. A modified Gompertz model was successfully used to predict the bacterial growth on these amides, which, according to a literature search, is likely a unique approach. Analyses of key growth characteristics revealed the best growth substrate among these amides was acrylamide. HPLC examination detected acrylamide's breakdown product, acrylic acid, proving the presence of degradation. Molybdenum blue production need a low phosphate concentration. According to the scanning absorption spectra, the Mo-blue is most likely phoshomolybdate in its reduced form. Mo-blue synthesis was shown to be inhibited by a number of harmful cationic heavy metals. In bioremediation, the capacity of this bacteria to detoxify molybdenum and amides is helpful. The degradation of amides is now being studied in great detail. This bacteria's Mo-reducing enzyme is also being purified, and a molecular identification of the organism is being conducted. 


\section{REFERENCES}

1. Ambily PS, Jisha MS. Biodegradation of anionic surfactant, sodium dodecyl sulphate by Pseudomonas aeruginosa MTCC 10311. J Environ Biol. 2012;33(4):717-20.

2. Geng C, Gao Y, Li D, Jian X, Hu Q. Contamination investigation and risk assessment of molybdenum on an industrial site in China. J Geochem Explor. 2014;144(PB):273-81.

3. Jacobs JA, Lehr JH, Testa SM. Acid mine drainage, rock drainage, and acid sulfate soils: causes, assessment, prediction, prevention, and remediation. Hoboken, New Jersey: John Wiley \& Sons, Inc.; 2014.

4. Yu C, Xu S, Gang M, Chen G, Zhou L. Molybdenum pollution and speciation in Nver river sediments impacted with Mo mining activities in Western Liaoning, northeast China. Int J Environ Res. 2011;5(1):205-12.

5. Simeonov LI, Kochubovski MV, Simeonova BG. Environmental heavy metal pollution and effects on child mental development. Dordrecht: Springer Netherlands; 2011. (NATO Science for Peace and Security Series C: Environmental Security; vol. 1).

6. LeGendre GR, Runnells DD. Removal of dissolved molybdenum from wastewaters by precipitates of ferric iron. Environ Sci Technol. 1975;9(8):744-9.

7. Kargar M, Khorasani N, Karami M, Rafiee G-R, Naseh R. Study of aluminum, copper and molybdenum pollution in groundwater sources surrounding (Miduk) Shahr-e- Babak copper complex tailings dam. World Acad Sci Eng Technol. 2011;76:412-6.

8. Yong FS. Mamut copper mine - The untold story. The national seminar on the Malaysian minerals industry. Miner Underpinning Yesterdays Needs Todays Dev Tomorrows Growth. 2000;

9. Apte SC, Kwong YTJ. Deep sea tailings placement: critical review of environmental issues. CSIRO Australia and CANMET Canada; 2003.

10. Angel BM, Simpson SL, Jarolimek CV, Jung R, Waworuntu J, Batterham G. Trace metals associated with deep-sea tailings placement at the Batu Hijau copper-gold mine, Sumbawa, Indonesia. Mar Pollut Bull. 2013;73(1):306-13.

11. Tucker MD a, Barton LL b, Thomson BM c. Reduction and immobilization of molybdenum by Desulfovibrio desulfuricans. J Environ Qual. 1997;26(4):1146-52.

12. Capaldi A, Proskauer B. Beiträge zur Kenntniss der Säurebildung bei Typhus-bacillen und Bacterium coli - Eine differentialdiagnostische Studie. Z Für Hyg Infect. 1896;23(3):452-74.

13. Ghani B, Takai M, Hisham NZ, Kishimoto N, Ismail AKM, Tano $\mathrm{T}$, et al. Isolation and characterization of a $\mathrm{Mo}^{6+}$-reducing bacterium. Appl Environ Microbiol. 1993;59(4):1176-80.

14. Shukor MY, Ahmad SA, Nadzir MMM, Abdullah MP, Shamaan NA, Syed MA. Molybdate reduction by Pseudomonas sp. strain DRY2. J Appl Microbiol. 2010;108(6):2050-8.

15. Campbell AM, Del Campillo-Campbell A, Villaret DB. Molybdate reduction by Escherichia coli K-12 and its chl mutants. Proc Natl Acad Sci U S A. 1985;82(1):227-31.

16. Lim HK, Syed MA, Shukor MY. Reduction of molybdate to molybdenum blue by Klebsiella sp. strain hkeem. J Basic Microbiol. 2012;52(3):296-305.

17. Halmi MIE, Zuhainis SW, Yusof MT, Shaharuddin NA, Helmi W, Shukor Y, et al. Hexavalent molybdenum reduction to Mo-blue by a sodium-dodecyl-sulfate- degrading Klebsiella oxytoca strain dry 14. BioMed Res Int. 2013;2013.

18. Masdor N, Abd Shukor MS, Khan A, Bin Halmi MIE, Abdullah SRS, Shamaan NA, et al. Isolation and characterization of a molybdenum-reducing and SDS- degrading Klebsiella oxytoca strain Aft-7 and its bioremediation application in the environment. Biodiversitas. 2015;16(2):238-46.

19. Ahmad SA, Shukor MY, Shamaan NA, Mac Cormack WP, Syed MA. Molybdate reduction to molybdenum blue by an Antarctic bacterium. BioMed Res Int. 2013;2013.

20. Shukor MY, Rahman MF, Shamaan NA, Syed MS. Reduction of molybdate to molybdenum blue by Enterobacter sp. strain Dr.Y13. J Basic Microbiol. 2009;49(SUPPL. 1):S43-54.

21. Abo-Shakeer LKA, Ahmad SA, Shukor MY, Shamaan NA, Syed MA. Isolation and characterization of a molybdenum-reducing Bacillus pumilus strain lbna. J Environ Microbiol Toxicol. 2013;1(1):9-14.
22. Othman AR, Bakar NA, Halmi MIE, Johari WLW, Ahmad SA, Jirangon $\mathrm{H}$, et al. Kinetics of molybdenum reduction to molybdenum blue by Bacillus sp. strain A.rzi. BioMed Res Int. 2013;2013.

23. Shukor MY, Habib SHM, Rahman MFA, Jirangon H, Abdullah MPA, Shamaan NA, et al. Hexavalent molybdenum reduction to molybdenum blue by S. marcescens strain Dr. Y6. Appl Biochem Biotechnol. 2008;149(1):33-43.

24. Rahman MFA, Shukor MY, Suhaili Z, Mustafa S, Shamaan NA, Syed MA. Reduction of Mo(VI) by the bacterium Serratia sp. strain DRY5. J Environ Biol. 2009;30(1):65-72.

25. Shukor MY, Rahman MF, Suhaili Z, Shamaan NA, Syed MA. Bacterial reduction of hexavalent molybdenum to molybdenum blue. World J Microbiol Biotechnol. 2009;25(7):1225-34.

26. Yunus SM, Hamim HM, Anas OM, Aripin SN, Arif SM. Mo (VI) reduction to molybdenum blue by Serratia marcescens strain Dr. Y9. Pol J Microbiol. 2009;58(2):141-7.

27. Kessler KL, Olson KC, Wright CL, Austin KJ, Johnson PS, Cammack KM. Effects of supplemental molybdenum on animal performance, liver copper concentrations, ruminal hydrogen sulfide concentrations, and the appearance of sulfur and molybdenum toxicity in steers receiving fiber-based diets. J Anim Sci. 2012;90(13):5005-12.

28. Chopikashvili LV, Bobyleva LA, Zolotareva GN. Genotoxic effects of molybdenum and its derivatives in an experiment on Drosophila and mammals. Tsitol Genet. 1991:25(5):45-9.

29. Titenko-Holland N, Shao J, Zhang L, Xi L, Ngo H, Shang N, et al. Studies on the genotoxicity of molybdenum salts in human cells in vitro and in mice in vivo. Environ Mol Mutagen. 1998;32(3):2519.

30. Pandey G, Jain GC. Molybdenum induced histopathological and histomorphometric alterations in testis of male Wistar rats. Int $\mathbf{J}$ Curr Microbiol Appl Sci. 2015;4(1):150-61.

31. Yamaguchi S, Miura C, Ito A, Agusa T, Iwata H, Tanabe S, et al Effects of lead, molybdenum, rubidium, arsenic and organochlorines on spermatogenesis in fish: Monitoring at Mekong Delta area and in vitro experiment. Aquat Toxicol. 2007;83(1):4351.

32. Rahim MBH, Syed MA, Shukor MY. Isolation and characterization of an acrylamide-degrading yeast Rhodotorula sp. strain $\mathrm{MBH} 23$ KCTC 11960BP. J Basic Microbiol. 2012;52(5):573-81.

33. Svensson K, Abramsson L, Becker W, Glynn A, Hellenäs K-E, Lind Y, et al. Dietary intake of acrylamide in Sweden. Food Chem Toxicol. 2003;41(11):1581-6.

34. Smith EA, Prues SL, Oehme FW. Environmental degradation of polyacrylamides. 1 . Effects of artificial environmental conditions: Temperature, light, and $\mathrm{pH}$. Ecotoxicol Environ Saf 1996;35(2):121-35.

35. Rogacheva SM, Ignatov OV. The respiratory activity of Rhodococcus rhodochrous M8 cells producing nitrile-hydrolyzing enzymes. Appl Biochem Microbiol. 2001;37(3):282-6.

36. Holt JG, Krieg NR, Sneath PHA, Staley JT, Williams ST. Bergey's Manual of Determinative Bacteriology. 9th ed. Lippincott Williams \& Wilkins; 1994

37. Costin S, Ionut S. ABIS online - bacterial identification software, http://www.tgw1916.net/bacteria_logare.html, database version Bacillus 022012-2.10, accessed on Mar 2015. 2015.

38. Shukor MS, Shukor MY. A microplate format for characterizing the growth of molybdenum-reducing bacteria. J Environ Microbiol Toxicol. 2014;2(2):42-4.

39. Arif NM, Ahmad SA, Syed MA, Shukor MY. Isolation and characterization of a phenol-degrading Rhodococcus sp. strain AQ5NOL 2 KCTC 11961BP. J Basic Microbiol. 2013:53(1):9-19.

40. Shukor MY, Gusmanizar N, Ramli J, Shamaan NA, MacCormack WP, Syed MA. Isolation and characterization of an acrylamidedegrading Antarctic bacterium. J Environ Biol. 2009;30(1):107-12.

41. Jan A. La reduction biologique du molybdate d'ammonium par les bactéries du genre Serratia (The biological reduction of ammonium molybdate by the bacteria of the Serratia kind). Bull Sci Pharmacol. 1939;46:336-9.

42. Shukor MY, Rahman MF, Suhaili Z, Shamaan NA, Syed MA Hexavalent molybdenum reduction to Mo-blue by Acinetobacter calcoaceticus. Folia Microbiol (Praha). 2010;55(2):137-43.

43. Holt JG, Krieg NR, Sneath PHA, Staley JT, Williams ST. Bergeys Man Determinative Bacteriol. 1994, 
44. Rege MA, Petersen JN, Johnstone DL, Turick CE, Yonge DR, Apel WA. Bacterial reduction of hexavalent chromium by Enterobacter cloacae strain H01 grown on sucrose. Biotechnol Lett. 1997;19(7):691-4

45. Elangovan R, Philip L, Chandraraj K. Hexavalent chromium reduction by free and immobilized cell-free extract of Arthrobacter rhombi-RE. Appl Biochem Biotechnol. 2010;160(1):81-97.

46. Krishnan CV, Garnett M, Chu B. Influence of $\mathrm{pH}$ and acetate on the self-assembly process

of $\left(\mathrm{NH}_{4}\right)_{42} \cdot \mathrm{Mo} \mathrm{VI}_{72} \mathrm{MoV}_{60} \mathrm{O}_{372}\left(\mathrm{CH}_{3} \mathrm{COO}\right)_{30}\left(\mathrm{H}_{2} \mathrm{O}\right)_{72}$.ca. $300 \mathrm{H}_{2} \mathrm{O}$. Int $\mathrm{J}$ Electrochem Sci. 2008;3(11):1299-315.

47. Barrows JN, Jameson GB, Pope MT. Structure of a heteropoly blue. The four-electron reduced $\beta$-12-molybdophosphate anion. J Am Chem Soc. 1985;107(6):1771-3.

48. Glenn JL, Crane FL. Studies on metalloflavoproteins. V. The action of silicomolybdate in the reduction of cytochrome $\mathrm{c}$ by aldehyde oxidase. Biochim Biophys Acta. 1956;22(1):111-5.

49. Chae HK, Klemperer WG, Marquart TA. High-nuclearity oxomolybdenum(V) complexes. Coord Chem Rev. 1993;128(12):209-24.

50. Shukor MY, Halmi MIE, Rahman MFA, Shamaan NA, Syed MA. Molybdenum reduction to molybdenum blue in Serratia sp. strain DRY5 is catalyzed by a novel molybdenum-reducing enzyme. BioMed Res Int. 2014;2014.

51. Shukor Y, Adam H, Ithnin K, Yunus I, Shamaan NA, Syed A. Molybdate reduction to molybdenum blue in microbe proceeds via a phosphomolybdate intermediate. J Biol Sci. 2007;7(8):1448-52.

52. Clesceri LS, Greenberg AE, Trussell RR. Standard methods for the examination of water and wastewater. Port City Press, Baltimore; 1989.

53. Myers CR, Carstens BP, Antholine WE, Myers JM. Chromium(VI) reductase activity is associated with the cytoplasmic membrane of anaerobically grown Shewanella putrefaciens MR-1. J Appl Microbiol. 2000;88(1):98-106.

54. Sims RPA. Formation of heteropoly blue by some reduction procedures used in the micro-determination of phosphorus. The Analyst. 1961;86(1026):584-90

55. Baranyi J, Roberts TA. A dynamic approach to predicting bacterial growth in food. Int J Food Microbiol. 1994;23(3-4):277-94.

56. Chang YC, Nawata A, Jung K, Kikuchi S. Isolation and characterization of an arsenate-reducing bacterium and its application for arsenic extraction from contaminated soil. J Ind Microbiol Biotechnol. 2012;39(1):37-44

57. Losi ME, Frankenberger Jr. WT. Reduction of selenium oxyanions by Enterobacter cloacae strain SLD1a-1: Reduction of selenate to selenite. Environ Toxicol Chem. 1997;16(9):1851-8.

58. Llovera S, Bonet R, Simon-Pujol MD, Congregado F. Chromate reduction by resting cells of Agrobacterium radiobacter EPS-916. Appl Environ Microbiol. 1993;59(10):3516-8.

59. Antipov AN, Lyalikova NN, Khijniak TV, L'vov NP. Vanadate reduction by molybdenum-free dissimilatory nitrate reductases from vanadate-reducing bacteria. IUBMB Life. 2000;50(1):39-42.

60. Shukor MY, Rahman MFA, Shamaan NA, Lee CH, Karim MIA, Syed MA. An improved enzyme assay for molybdenum-reducing activity in bacteria. Appl Biochem Biotechnol. 2008;144(3):293300 .

61. Medjeber N, Abbouni B, Menasria T, Beddal A, Cherif N. Screening and production of polyhydroxyalcanoates by Bacillus megaterium by the using cane and beet molasses as carbon sources. Pharm Lett. 2015;7(6):102-9.

62. Shukor MY, Syed MA, Lee CH, Karim MIA, Shamaan NA. A method to distinguish between chemical and enzymatic reduction of molybdenum in Enterobacter cloacae strain 48. Malays J Biochem. 2002;7:71-2.

63. Keyhan M, Ackerley DF, Matin A. Targets of improvement in bacterial chromate bioremediation. In: Pellei M, Porta A, editors. Remediation of Contaminated Sediments. Columbus, OH: Battelle Press; 2003.

64. Fujita M, Ike M, Nishimoto S, Takahashi K, Kashiwa M. Isolation and characterization of a novel selenate-reducing bacterium, Bacillus sp. SF-1. J Ferment Bioeng. 1997;83(6):517-22.

65. Stone J, Stetler L. Environmental Impacts from the North Cave Hills Abandoned Uranium Mines, South Dakota. In: Merkel BroderJ, Hasche-Berger A, editors. Uranium, Mining and Hydrogeology [Internet]. Springer Berlin Heidelberg; 2008. p. 371-
80. Available from: http://dx.doi.org/10.1007/978-3-540-877462 -48

66. Jenkins SH. Phosphorus in fresh water and the marine environment. Biol Conserv. 1973;5(2):95

67. Anu M, Salom Gnana TV, Reshma JK. Simultaneous phenol degradation and chromium (VI) reduction by bacterial isolates. Res J Biotechnol. 2010;5(1):46-9

68. Komeda H, Harada H, Washika S, Sakamoto T, Ueda M, Asano Y. A novel R-stereoselective amidase from Pseudomonas sp. MCI3434 acting on piperazine-2-tert-butylcarboxamide. Eur J Biochem. 2004;271(8):1580-90.

69. Liu Z-H, Cao Y-M, Zhou Q-W, Guo K, Ge F, Hou J-Y, et al Acrylamide biodegradation ability and plant growth-promoting properties of Variovorax boronicumulans CGMCC 4969. Biodegradation. 2013;24(6):855-64.

70. Nawaz MS, Chapatwala KD, Wolfram JH. Degradation of acetonitrile by Pseudomonas putida. Appl Environ Microbiol. 1989;55(9):2267-74.

71. Chandrashekar V, Chandrashekar C, Shivakumar R, Bhattacharya S, Das A, Gouda B, et al. Assessment of acrylamide degradation potential of Pseudomonas aeruginosa BAC-6 isolated from industrial effluent. Appl Biochem Biotechnol. 2014;173(5):113544.

72. Lakshmikandan M, Sivaraman K, Raja SE, Vasanthakumar P, Rajesh RP, Sowparthani K, et al. Biodegradation of acrylamide by acrylamidase from Stenotrophomonas acidaminiphila MSU12 and analysis of degradation products by MALDI-TOF and HPLC. Int Biodeterior Biodegrad. 2014;94:214-21.

73. Buranasilp K, Charoenpanich J. Biodegradation of acrylamide by Enterobacter aerogenes isolated from wastewater in Thailand. Environ Sci. 2011;23(3):396-403.

74. Postec A, Pignet P, Cueff-Gauchard V, Schmitt A, Querellou J, Godfroy A. Optimisation of growth conditions for continuous culture of the hyperthermophilic archaeon Thermococcus hydrothermalis and development of sulphur-free defined and minimal media. Res Microbiol. 2005;156(1):82-7.

75. Alt J, Krisch K, Hirsch P. Isolation of an inducible amidase from Pseudomonas acidovorans AEI. J Gen Microbiol. 1975;87(2):26072.

76. Ciskanik LM, Wilczek JM, Fallon RD. Purification and characterization of an enantioselective amidase from Pseudomona chlororaphis B23. Appl Environ Microbiol. 1995;61(3):998-1003.

77. Halmi MIE, Shukor MS, Johari WLW, Shukor MY. Mathematical modelling of the degradation kinetics of Bacillus cereus grown on phenol. J Environ Bioremediation Toxicol. 2014;2(1):1-5.

78. Syed MA, Ahmad SA, Kusnin N, Shukor MYA. Purification and characterization of amidase from acrylamide-degrading bacterium Burkholderia sp. strain DR.Y27. Afr J Biotechnol. 2012;11(2):32936.

79. Nawaz MS, Billedeau SM, Cerniglia CE. Influence of selected physical parameters on the biodegradation of acrylamide by immobilized cells of Rhodococcus sp. Biodegradation. 1998;9(5):381-7.

80. Thanyacharoen U, Tani A, Charoenpanich J. Isolation and characterization of Kluyvera georgiana strain with the potential for acrylamide biodegradation. J Environ Sci Health - Part ToxicHazardous Subst Environ Eng. 2012;47(11):1491-9. 